\title{
Simvastatin のラット血墏，肝および小腸
}

\section{ミクロソームにおける加水分解酵素}

\author{
今井 直子, 大多和昌克 \\ 萬有製薬株式会社 開発研究所薬物代謝研究部 ₹153 東京都目黑区下目黑2-9-3
}

Key words : simvastatin, rat, plasma, liver, intestine, carboxylesterase

\section{Ring-opening hydrolases for simvastatin in plasma, liver and intestinal microsomes of rats}

Naoko Imai and Masakatsu OHtawa

Development Laboratories, Banyu Pharmaceutical Co., Ltd., 2-9-3 Shimomeguro, Meguro-ku, Tokyo 153, Japan

\section{Summary}

The characterization of the hydrolase responsible for the ring-opening hydrolysis of simvastatin (SV) to its open acid form (SVA) was carried out using rat plasma, liver and intestinal microsomes.

The optimum $\mathrm{pHs}$ for the ring-opening hydrolase in plasma, liver and intestine were found to be between $\mathrm{pH} 7-8$.

The values of Vmax for plasma, liver and intestine were $0.33,0.97$ and $0.24 \mathrm{nmol} / \mathrm{min} / \mathrm{mg}$ protein, respectively, and the corresponding values of $\mathrm{Km}$ were $21.9,203.3$ and $567.6 \mu \mathrm{M}$, respectively. The value of $\mathrm{Vmax} / \mathrm{Km}$ for plasma hydrolase showed the largest value of $0.0154 \mathrm{ml} / \mathrm{min} / \mathrm{mg}$ protein, which is 3. $2^{-}$and 38 -fold larger than those for the liver and intestine, respectively.

The enzymatic hydrolysis of SV in the presence of plasma was inhibited by addition of diisopropyl fluorophosphate (DFP), bis ( $\mathrm{p}$-nitrophenyl) phosphate (BNPP), high concentration of physostigmine (Phys) and $\alpha$-naphthyl acetate $(\alpha-\mathrm{NA})$. In liver, the enzymatic hydrolysis of SV was inhibited by DFP, BNPP, $\alpha-\mathrm{NA}$ and EDTA. These results suggested that carboxylesterase might be, in part, responsible for the hydrolysis of SV in the plasma and liver. However, the difference in the inhibition patterns between plasma and liver indicated that different esterase isozymes might be responsible for the hydrolysis. On the other hand, the hydrolysis of SV by the intestine was not affected at all by the inhibitors and substrates mentioned above except EDTA, suggesting that the hydrolase in the intestine is different from those present in the plasma and liver. 


\section{緒 言}

Simvastatin（SV）はラクトン型プロドラッ グであり, HMG-CoA 還元酵素の特異的かつ強 力な阻害剂であり1)，実験動物2 4) およびヒト5) において経口投与により著明なコレステロール低 下作用が認められている. SV は投与後生体内で ラクトン部分が加水分解し, 活性型のオープンア シッド体（SVA）に変換される．SV のラクト ン部分はラットおよびゥサギ血漿中で速やかに加 水分解を受けるが，イヌ扣よびヒト血漿中では注 とんど加水分解を受けないことはすで報告され ている6). また，以前われわれは，雄ラットに SV を経口投与した後の, 血漿, 小腸, 肝臓, 胆 汁中および尿中代謝物を分別定量し，小腸では未 変化体である SV と加水分解を受けた SVA は 注涪同程度存在するが，血漿，肝臓，胆汁中括よ び尿中ではラクトン体は極めて微量か，あるいは ほとんど検出されないことを報告した77。 また， 肝臓中の主代謝物は SVA であったことより, $\mathrm{SV}$ は経口投与後, 肝臓に到達する以前に大部分 が SVA に加水分解されると考光られている.

そこで今回, 雄ラットの血漿, 肝蔵および小腸 ミクロソームを用い, SV の加水分解酵素の性質 を in vitro で調ベ, ラットに护ける体内動態に いくつかの考察を与えたので報告する.

\section{実験材料および方法}

\section{1. 被験物質および試薬}

SV とその開環体である SVA (Fig. 1) およ び MK-803 (lovastatin) は, 米国 Merck 社 より提供された. ラットアルブミン（フラクショ
ンV）は, Sigma 社製を使用した。 その他の試 薬はすべて市販の特級品を使用した。

\section{2. 実験動物および試料の採取}

Sprague-Dawley 系雄性ラット（7 週齛) （日本チャールス・リバー）を用いた。室温 $24 \pm 3$ ${ }^{\circ} \mathrm{C}$ ，湿度 $55 \pm 15 \% ， 12$ 時間の照明サイクルの条件 下で約 1 週間予備飼育した。使用前15時間絶食さ せた。エーテル麻酔下で, 腹大動脈より血液を採 取し, ヘパリン存在下 $3000 \mathrm{rpm}, 10$ 分間遠心分離 して血漿を得た。肝臓は，承冷 $1.15 \% \mathrm{KCl} / 0.01$ $\mathrm{M}$ ナトリウムーカリウムリン酸緩衝液（ $\mathrm{pH}$ 7.2） 約 $25 \mathrm{~m} l$ を用いて灌流した後摘出し，湿重量を測 定した。小腸は，胃幽門部から $10 \mathrm{~cm}$ の下部拈よ び盲腸から $10 \mathrm{~cm}$ の上部を切断し，内容物を 1.15 $\% \mathrm{KCl} / 0.01 \mathrm{M}$ ナトリウムーカリウムリン酸緩 衝液（pH 7.2）にて洗浄後, 湿重量を測定した。

\section{3. 肝および小腸ミクロソームの調製}

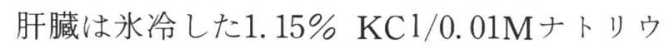

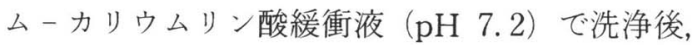
細切し, 3 倍容 (v/w) の水冷1. 15\% KCl/0.01 $\mathrm{M}$ ナトリウムーカリウムリン酸緩衝液 $(\mathrm{pH} 7.2)$ を加え，テフロンーガラスホモジナイザーを用い て粗ホモジネートを調製した，以上の操作はすべ て氷冷下で行った。粗ホモジネートを $10000 \times \mathrm{g}$, $4{ }^{\circ} \mathrm{C}$ で20分間, 高速冷却遠心機(HITACHI, SCR 20BA 型）にて遠心分離し，得られた上清をS-10 とした. S-10 $3 \mathrm{ml}$ を $100000 \times \mathrm{g}, 4{ }^{\circ} \mathrm{C}$ で 60 分間， 超高速遠心機（BECKMAN, L8-80M型）にて 遠心分離した. 上清を廃棄した後, 沈椬に $0.1 \mathrm{M}$ ナトリウムーカリウムリン酸緩衝液 $(\mathrm{pH}$ 7.2)

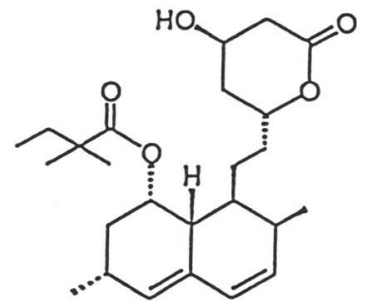

SV

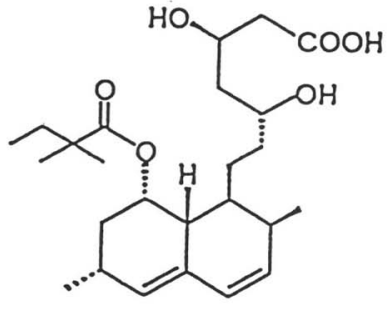

SVA

Fig. 1 Hydrolysis of SV to SVA 
$1.5 \mathrm{~m} l$ を加光，ソニケーター(SEIKO INST．\& ELECTRONICS LTD., SH-7040) を用いて ホモジナイズし，得られた懸濁液をミクロソーム 酵素標品として使用した. 小腸は, 細切した後, 湿重量の 3 倍容の $1.15 \% \mathrm{KCl} / 0.01 \mathrm{M}$ ナトリウ ムーカリウムリン酸緩衝液（pH 7.2）を添加後, POLYTRON ${ }^{\circledR}$ (KINEMATICA, GmbH) に てホモジナイズした。 以後は肝ミクロソーム調製 方法に従った。 各ミクロソーム酵素標品および血 漿の蛋白濃度は, ウシ血清アルブミンを標準溶液 として, Lowry らの方法8）により測定した.

\section{4. 非酵素的加水分解反応 ( $\mathbf{p H}$ の影響)}

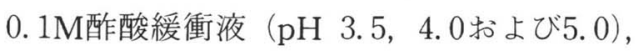
$0.1 \mathrm{M}$ リン酸緩衝液（ $\mathrm{pH}$ 6.0，7.0および8.0）お よび0.1Mトリスー塩酸緩衝液（ $\mathrm{pH} 9.0 ） を$ をい た. 各 $\mathrm{pH}$ の緩衝液 $1.0 \mathrm{~m} l$ に SV $100 \mu \mathrm{M}$ ある いは $200 \mu \mathrm{M}$ (アセトン溶液) を添加し, $37^{\circ} \mathrm{C}, 10$ 分間あるいは30分間インキュベートした．酢酸エ チル $3.0 \mathrm{~m} l$ にて反応を停止後, 遠心分離し, 有 機層 $2.0 \mathrm{~m} l$ を分取した. 濃縮乾固後, 残渣を 0.25 $\mathrm{m} l$ のアセトニトリル $/$ 水 $=6 / 4(\mathrm{v} / \mathrm{v})$ に溶解し, HPLC にて生成したSVA を分離定量した. 検 量線の作成は, 各 $\mathrm{pH}$ の緩衝液 $1.0 \mathrm{~m} l$ に酢酸エ チル $3.0 \mathrm{~m} l$ を添加した後 SVA 標品（0.05〜10 $\mu \mathrm{M})$ を添加し，同様の操作を行った.

\section{5. アルブミンによる加水分解}

$4 \%(\mathrm{w} / \mathrm{v})$ ラットアルブミン（フラクション $\mathrm{V})$ 水溶液 $0.1 \mathrm{~m} l$ を0.1Mナトリウム - カリウム リン酸緩衝液（pH 7.2）に添加し, $1 \mathrm{~m} l$ の反 応溶液とした. $37^{\circ} \mathrm{C} て, S V 100 \mu \mathrm{M}$ の添加に よって反応を開始し，2，5，10，20および30分間 インキュベーション後, 䣫酸ェチル $3.0 \mathrm{~m} l$ にて 反応を停止した。 以後の操作は, 上記方法に従っ た、なお，対照としてラットアルブミン水溶液の かわりに生理食塩水 $0.1 \mathrm{~m} l$ を用いた.

\section{6. 酵素活性の测定}

標準的なインキュベーション溶液は，血漿では， 血漿 $(0.1 \mathrm{~m} l), 100 \mu \mathrm{M}$ の SV および0.1Mナト

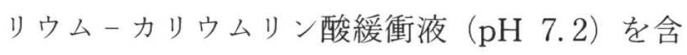
む $1.0 \mathrm{ml}$ の溶液とした。肝および小腸ミクロ
ソーム中では, 各酵素 (1.1 mg 2. $2 \mathrm{mg}$ 蛋白), $200 \mu \mathrm{M}$ の SV および0.1Mナトリウムーカリウ ムリン酸緩衝液 $(\mathrm{pH} 7.2)$ を含む $1.0 \mathrm{ml}$ の溶液 とした。

血漿は $37^{\circ} \mathrm{C}$ で 5 分間のプレインキュベーション の後, SV を添加し反応を開始した. 10分間のイ ンキュベーションの後, 酢酸エチル $3.0 \mathrm{~m} l$ を添 加し反応を停止した. 試料を擋汼後, 遠心分離し, 有機層 $2.0 \mathrm{~m} l$ を分取し, 濃縮乾固した。残椬を $0.25 \mathrm{~m} l$ のアセトニトリル $/$ 水 $=6 / 4(\mathrm{v} / \mathrm{v})$ に溶 解し，HPLC で SVA を定量した．肝および小 腸ミクロソームでは基質である SV を添加した 後, 直ちに反応を開始し, $37^{\circ} \mathrm{C} て ゙ 30$ 分間インキュ ベートした．以後の操作は血漿中酵素活性測定の 方法に従った，検量線の作成は，打のおのの酵素 標準溶液 $1.0 \mathrm{~m} l$ に酢酸エチル $3.0 \mathrm{~m} l$ を添加した 後, SVA 標品 $(0.05 \sim 10 \mu \mathrm{M})$ を添加し, 同様 の操作を行った. 各酵素反応のブランクとして, 血漿および各酵素標品のかわりに同容量の0.1M ナトリウムーカリウムリン酸緩衝液 $(\mathrm{pH} 7.2)$ を添加したものを用いた。

\section{1) 至適 $\mathrm{pH}$}

$0.1 \mathrm{M}$ 酶酸緩衝液（ $\mathrm{pH} 3.5 ， 4.0$ および5.0)，

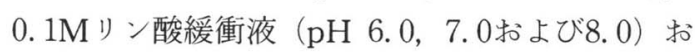
よび0.1Mトリス - 塩酸緩衝液（ $\mathrm{pH}$ 9.0）を用い, 上述の方法に従い, 抒の扮のの $\mathrm{pH}$ に打子る血 漿, 肝および小腸ミクロソームでの SV の加水 分解反応を測定した。なお，各 $\mathrm{pH}$ に打ける酵 素反応のブランクとして, 血漿および各酵素標品 のかわりに同容量の0.1Mナトリウムーカリウム リン酸緩衝液（ $\mathrm{pH}$ 7.2）を用いた。

\section{2) Kinetic constants $の$ 測定}

基質 $(\mathrm{SV})$ 濃度は，血漿では $1 \mu \mathrm{M}$ から $500 \mu \mathrm{M}$, 肝拉よび小腸ミクロソームでは $20 \mu \mathrm{M}$ から $1000 \mu$

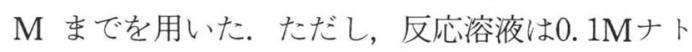
リウムーカリウムリン酸緩衝液 $(\mathrm{pH} 7.2)$ を含 む $1 \mathrm{~m} l$ とした、 Vmaxおよび $\mathrm{Km}$ 值の算出は Lineweaver-Burk の逆数プロット法9)によっ た.

\section{3）各種阻害剤の影響}

エステラーゼの阻害剤として, diisopropyl fluorophosphate (DFP), bis (p-nitrophenyl) phosphate (BNPP) および physostigmine 
(Phys）を用いた。 また，エステラーゼの競合的 基質として $\alpha$-naphthyl acetate ( $\alpha$-NA), phenyl acetate (PhA), acetylcholine ( $\mathrm{ACh})$, benzoylcholine $(\mathrm{BzCh})$, mevalonolactone (MVL) および $\delta$-gluconolactone $(\delta$-GL) を 用いた。な拈，金属キレート剤としてEDTAを

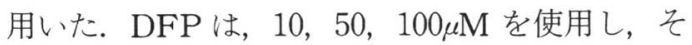
の他は10，100，1000 $\mu \mathrm{M}$ を使用した. MVL お よび EDTA は20，200，2000 $\mu \mathrm{M}$ を使用した。

各阻害剂および基質は，あらかじめ酵素反応溶 液中に添加し, 血墏では 5 分, 肝および小腸ミク ロソームでは10分間のプレインキュベーションの 後, SV の添加により反応を開始した. ただし, MVL は基質との同時添加により反応を開始し た、な和対照として各阻害剂および基質のかわり に，阻害剤および基質の調製に用いたアセトンま たは水を同容量添加した。

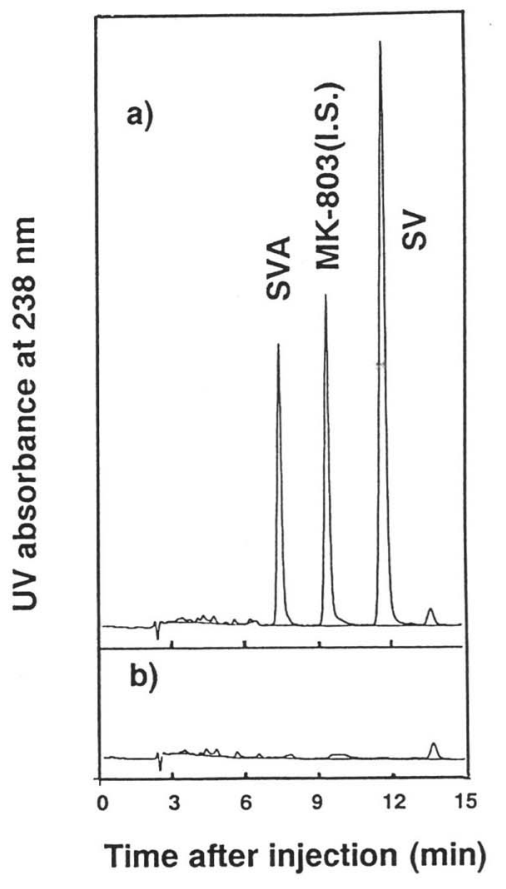

Fig. 2 HPLC profiles of SV and its metabolite formed by plasma from male rats.

a) $\mathrm{SV}(10 \mu \mathrm{M})$ was incubated at $37^{\circ} \mathrm{C}$ for 10 min with plasma from male rats. b) Blank : Male rat plasma was incubated at $37^{\circ} \mathrm{C}$ for $10 \mathrm{~min}$ in the absence of SV.

\section{HPLC による SVA の分離定量}

$\mathrm{SV}$ と各種酵素との反応後, 生成したSVAを HPLC にて分離定量した.

HPLC は, UV 検出器 (UV-DEC-100-VI) を装備した TRI-ROTAR VI HPLC システム (日本分光), あるいは UV 検出器 (875-UV) を装備した801-SC system controller により 制御される HPLC システム（日本分光）を用 いた。 カラムは，ガードカラム LiChroCART ${ }^{\circledR}$ 4-4（LiChrospher ${ }^{\circledR} 100, R P-18 \mathrm{e}, 50 \mathrm{~mm} \times 4.6$ mm i.d., E. Merck）拈よび分離カラム Wakopak (NUCLEOSIL 5C18, $250 \mathrm{~mm} \times 4.6 \mathrm{~mm}$ i.d., 和光）を使用した. 移動相は, アセトニト リル $/ 25 \mathrm{mM} \mathrm{H}_{3} \mathrm{PO}_{4} / \mathrm{NH}_{4} \mathrm{H}_{2} \mathrm{PO}_{4}(\mathrm{pH} 3.0)=$ $65 / 35 （ \mathrm{v} / \mathrm{v})$ 溶液を用い, 流速 $1 \mathrm{ml} / \mathrm{min}$, カラ 么温度 $35^{\circ} \mathrm{C}$, 分析時間は 15 分とし, UV $238 \mathrm{~nm}$ の 吸収を測定した。内部標準物質として MK-803 を用いた。代表的な HPLC クロマトグラフを Fig. 2に示した. SVA の保持時間は7.4分, SV および MK-803はそれぞれ12.0分拉よび9.5分で あった。な沶，本法に拊ける SVA の定量限界 は0. $05 \mathrm{nmol} / \mathrm{ml}$ であった.

\section{実験結果}

\section{1. $\mathrm{pH}$ の影響}

$\mathrm{SV}$ の加水分解に及ぼす $\mathrm{pH}$ の影響について 検討した結果の一部を Fig. 3に示した. SV は 各 $\mathrm{pH}$ の緩衝液中に掉いて, $37^{\circ} \mathrm{C}, 30$ 分間のイ ンキュベーションでは, pH 6.0以下でほとんど 非酵素的に加水分解されなかったが，アルカリ側 では速やかな分解がみられた，一方，酵素的加水 分解の至適 $\mathrm{pH}$ は, 血漿, 肝臓および小腸では, $\mathrm{pH} 7$ ８であった。 なお， $\mathrm{pH} 7$ ～ 8 において SV から生成する代謝物は SVA のみであった (血漿抢よび小腸は未記載).

\section{2. アルブミンによる加水分解}

$4 \%$ ラットアルブミン水溶液 $0.1 \mathrm{~m} l$ を用い, $\mathrm{SV}$ の加水分解について検討した. SV はアルブミン と $37^{\circ} \mathrm{C} て ゙ 10$ 分間インキュベートすることにより， わずかに加水分解を受け SVA を生成したが, その生成量は, 同容量の血漿を用いた場合の約 12 \%であった。 


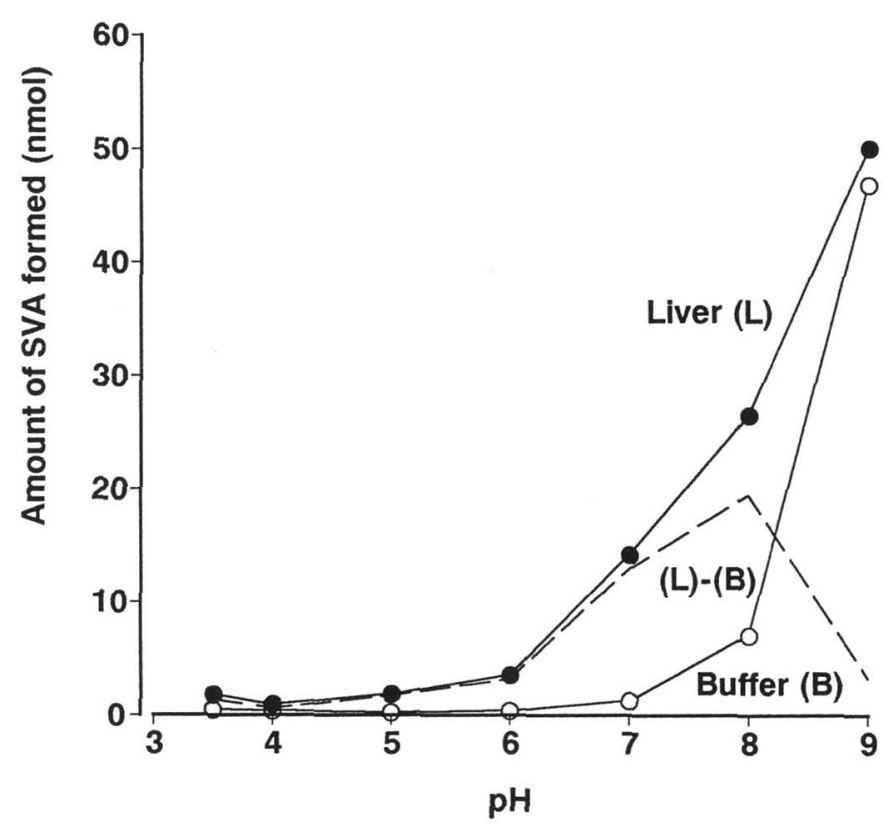

Fig. 3 Effect of $\mathrm{pH}$ on the ring-opening hydrolysis of SV. $\mathrm{SV}(200 \mu \mathrm{M})$ was incubated with rat liver microsomes (-) or buffer solution (O) under various $\mathrm{pHs}$ at $37^{\circ} \mathrm{C}$ for 30 min. Enzymatic hydrolysis $(\cdots)$ estimates as L-B.

Table I Kinetic constants for the ring-opening hydrolysis of $\mathrm{SV}$ by various tissues in rats

\begin{tabular}{lccc}
\hline \multicolumn{1}{c}{ Tissues } & $\mathrm{V}_{\max }{ }^{1)}$ & $\mathrm{Km}^{2)}$ & $\mathrm{Vmax} / \mathrm{Km}^{3)}$ \\
\hline Plasma $^{4)}$ & $0.33 \pm 0.06$ & $21.9 \pm 5.0$ & $15.4 \pm 1.4$ \\
Liver $^{5)}$ & $0.97 \pm 0.13$ & $203.3 \pm 32.0$ & $4.81 \pm 0.61$ \\
Intestine $^{5)}$ & $0.24 \pm 0.01$ & $567.6 \pm 15.7$ & $0.407 \pm 0.034$ \\
\hline
\end{tabular}
1) $\mathrm{nmol} / \mathrm{min} / \mathrm{mg}$ protein
2) $\mu \mathrm{M}$
3) $10^{-3} \mathrm{ml} / \mathrm{min} / \mathrm{mg}$ protein
4) SV $(100 \mu \mathrm{M})$ was incubated at $37^{\circ} \mathrm{C}$ for $10 \mathrm{~min}$.
5) $\mathrm{SV}(200 \mu \mathrm{M})$ was incubated at $37^{\circ} \mathrm{C}$ for $30 \mathrm{~min}$.

\section{Kinetic constants}

各組織中の SV から SVA への加水分解酵素 の kinetic constants を Table I に示した。 $\mathrm{pH} 7.2$ に和けるV max值は, 血漿で $0.33 \mathrm{nmol} /$ $\mathrm{min} / \mathrm{mg}$ protein, 肝蔵拉よび小腸ではそれぞ れ0.97および $0.24 \mathrm{nmol} / \mathrm{min} / \mathrm{mg}$ protein であ り, 肝ミクロソームで最も高い值を示した。一方, $\mathrm{Km}$ 值は，血漿，肝蔵および小腸でそれぞれ 21.9，203.3抢よび567.6 $\mu \mathrm{M}$ であり，血漿で最小 值を示した。 また，代謝能を示す $\mathrm{V} \max / \mathrm{Km}$ 值
を比較すると血漿で最高值を示し, 肝の3.2倍, 小腸の38倍であった。

\section{4. 阻害剂の影響}

血漿, 肝和よび小腸ミクロソームの SV 加水 分解酵素活性に及ぼす各種エステラーゼ阻害剤な らびに基質の添加の影響について検討した結果の 一部を Fig. 4〜6に示した. 血墏（Fig.4）では， DFP の添加により加水分解反応はほぼ完全に阻 害された. BNPP では, 酵素反応は用量依存的 


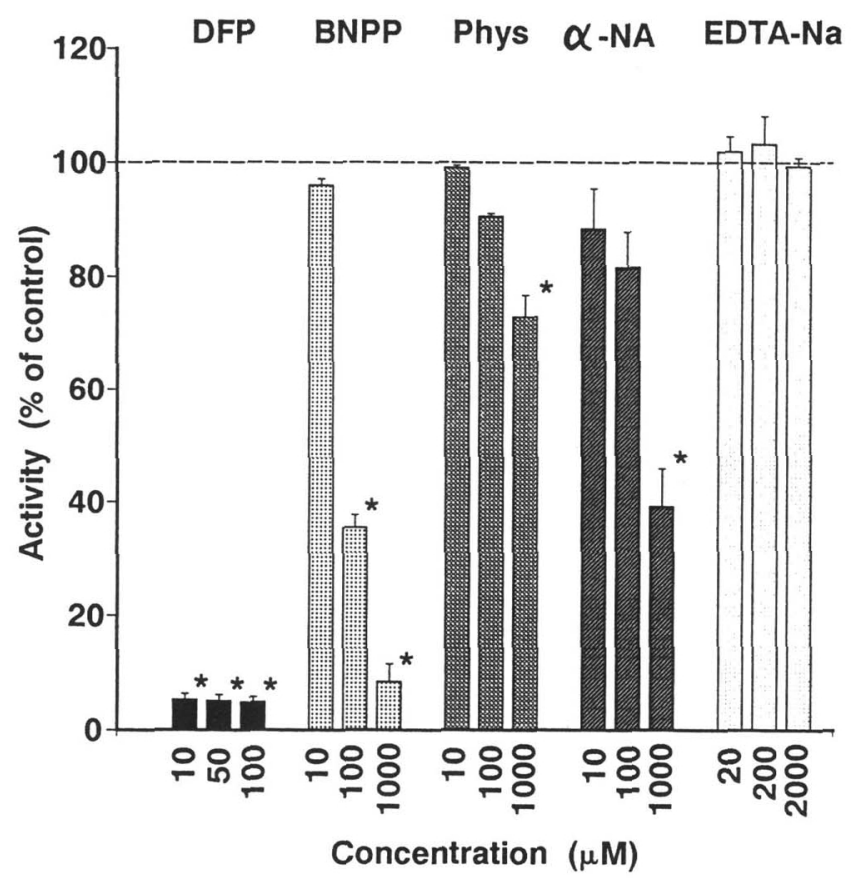

Fig. 4 Ring-opening hydrolysis of SV $(100 \mu \mathrm{M})$ by rat plasma in the presence of various reagents.

Activities are given in per cent of the control values. The values represent the mean $\pm \mathrm{S}$. D. of 3 rats. Control values are $0.241 \pm 0.056 \mathrm{nmol} / \mathrm{min} / \mathrm{mg}$ protein. Significant differences from the control values are marked ; $(\mathrm{p}<0.05)$.

に阻害され，アセチルコリンェステラーゼおよび コリンエステラーゼの阻害剤である Phys の添 加では高濃度でのみ阻害された，各種エステラー ゼの基質を用いて同様にとの影響について調べ た結果, カルボキシルェステラーゼの基質である $\alpha$-NA では用量依存的に阻害されたが，アセチ ルコリンェステラーゼおよびュリンェステラーゼ の基質である $\mathrm{ACh}$ 拈よび $\mathrm{BzCh}$ によっては, 何ら影響を受けなかった (データは未記載)。ま た，ラクトン環を持つ化合物である $\delta-\mathrm{GL}$ およ び MVLの添加の影響について調べたが，SVか ら SVA への加水分解反応に何ら影響はみられ なかった (データは未記載)。さらに, EDTA によっても酵素反応はほとんど影響を受けなかっ た、肝ミクロソーム（Fig.5）では, DFP およ び BNPP により SV の加水分解反応は用量依 存的に阻害されたが, Phys では阻害されなかっ た。また，各特異的基質を用いてその影響を調べ
た結果， $\alpha$-NA では SV の加水分解反応は用量 依存的に阻害されたが, $\mathrm{ACh}, \mathrm{BzCh}, \delta-\mathrm{GL}$ お よび MVL によっては阻害されなかった（デー タは未記載)。また, EDTA では用量依存的に 阻害された。一方, 小腸ミクロソーム (Fig. 6) では, DFP, BNPP および Phys のいずれに よっても加水分解反応は阻害されなかった。ささら に，アリルェステラーゼの基質である PhA K よっても酵素反応は全く阻害されず， $\alpha$ - NA, $\mathrm{ACh}, \mathrm{BzCh}, \delta-\mathrm{GL}$ および MVL のいずれに よっても同様に全く阻害を受けなかった（データ は未記載)。また，EDTA では，わずかではあ るが用量依存的に阻害された。

\section{考 察}

SV はpH 3.5 6.0の範囲では安定であったが, pH 7 からアルカリ側に拈いて非酵素的に速やか に加水分解された。血漿, 肝および小腸ミク口 


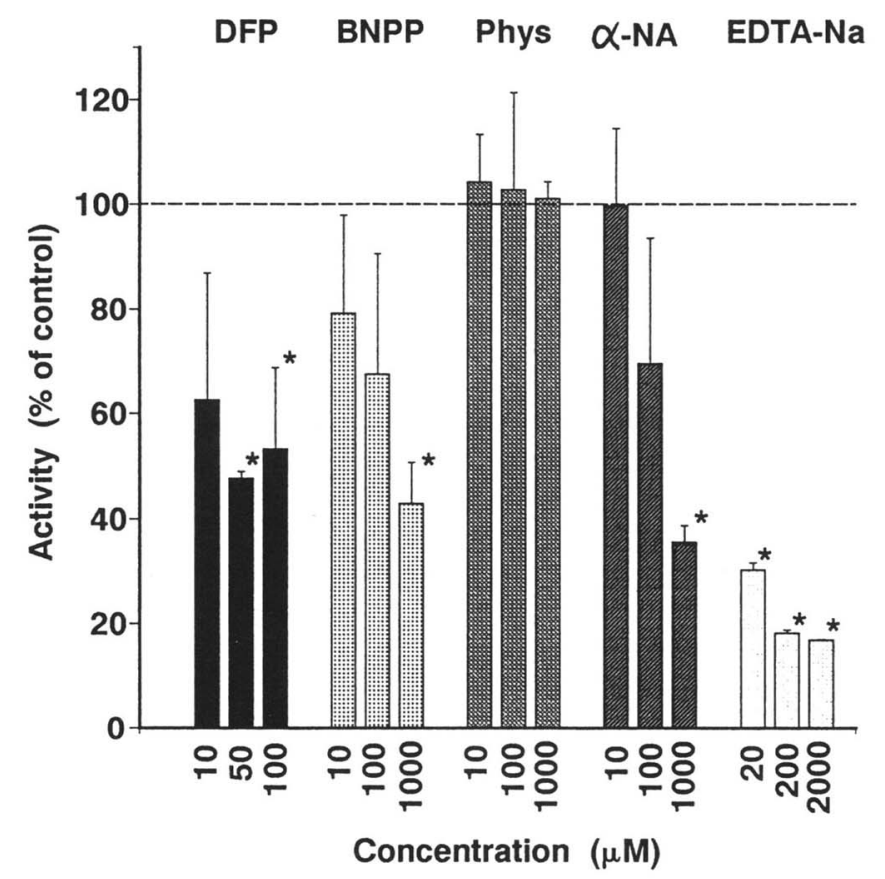

Fig. 5 Ring-opening hydrolysis of $\mathrm{SV}(200 \mu \mathrm{M})$ by rat liver microsomes in the presence of various reagents. Activities are given in per cent of the control values. The values represent the mean $\pm \mathrm{S}$. D. of 3 rats. Control values are $0.527 \pm 0.045 \mathrm{nmol} / \mathrm{min} / \mathrm{mg}$ protein. Significant differences from the control values are ma rked ; * $(\mathrm{p}<0.05)$.

ソームを用いて, 各加水分解の至適 $\mathrm{pH}$ につい て検討した結果, いずれの酵素についても $\mathrm{pH} 7$ 〜 8 付近であった.

アルブミンはエステラーゼ活性を持つことが知 られている10,11). そこで, 生体内の条件に近い 4 \%ラットアルブミン（フラクションV）水溶液を 用いて，加水分解反応を検討したが，SV はアル ブミンによってわずかに加水分解を受け SVA を生成したが，その生成量は同容量の血漿を用い た場合の約 $12 \%$ であり, ラット血漿中でみられる 高いSV 加水分解活性にはアルブミンの関与は 少ないことが推察された.

各組織中加水分解酵素の kinetic constants は, 各組織中酵素の至適 $\mathrm{pH}$ を考慮して, 生体内 $\mathrm{pH}$ に近い $\mathrm{pH} 7.2$ の条件下で測定し比較した. $\mathrm{pH}$ 7.2 に打けるVmax值は, 血漿で $0.33 \mathrm{nmol} / \mathrm{min} /$ mg protein, 肝蔵および小腸でそれぞれ0.97お よび $0.24 \mathrm{nmol} / \mathrm{min} / \mathrm{mg}$ protein であり, 肝ミ
クロソームで最も高い值を示した. 一方, $\mathrm{Km}$ 值 は, 血漿, 肝蔵および小腸でそれぞれ21.9, 203.3 および567. $6 \mu \mathrm{M}$ であり, 血漿で最小值を示した. 代謝能を示す V max $/ \mathrm{Km}$ 值を比較すると血漿が 最も高い值を示し, 肝の3.2倍, 小腸の38倍であ り，SV は主として血漿中で SVA へと代謝さ れるが, 肝ミクロソーム中酵素も SV の加水分 解反応に広く関与していることが推察される. こ れらのことから, SV は経口投与後, その多くが 未変化体のまま小腸から吸収された後, 肝臓に到 達するまでの間に血漿中加水分解酵素によって速 やかに加水分解されると思われる. 加水分解を逃 れた SV は肝臓においても広く加水分解される と考光られる. 本結果は, 以前われわれが報告し た SV の経口投与後の臓器内分布試験に打いて, 小腸には SV と SVA (一部は非酵素的加水分 解により生成）がほぼ同量存在し，肝および血漿 中ではラクトン体はほとんど確認できなかった結 


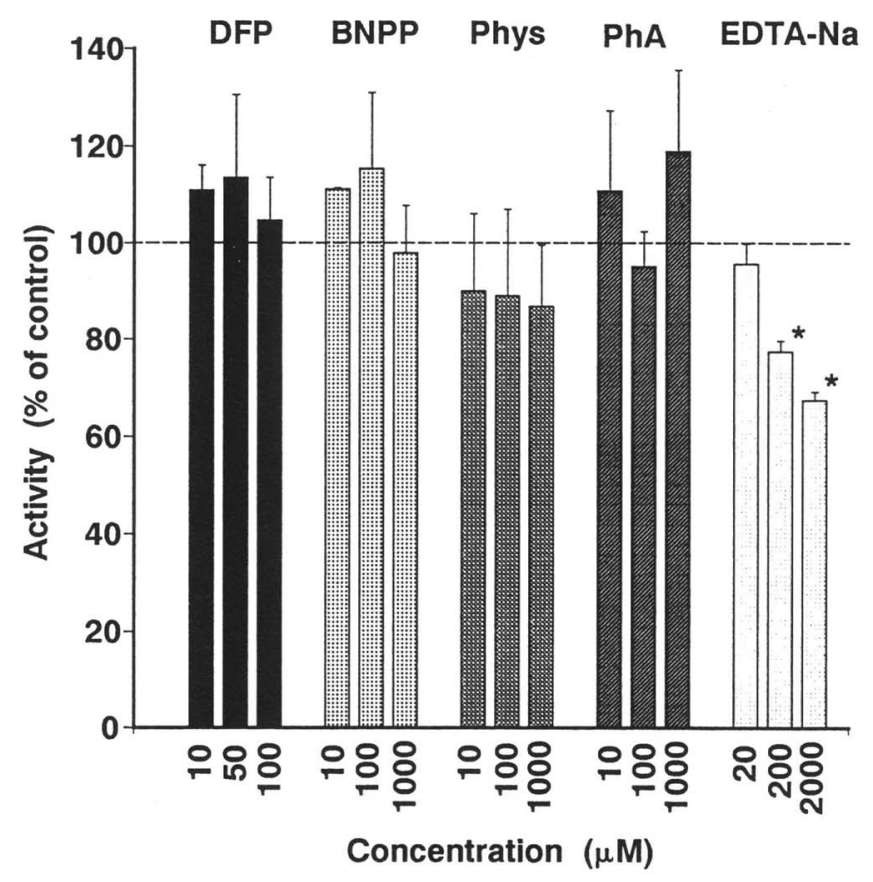

Fig. 6 Ring-opening hydrolysis of SV $(200 \mu \mathrm{M})$ by rat intestinal microsomes in the presence of various reagents.

Activities are given in per cent of the control values.

The values represent the mean $\pm \mathrm{S}$. D. of 3 rats.

Control values are $0.111 \pm 0.029 \mathrm{nmol} / \mathrm{min} / \mathrm{mg}$ protein.

Significant differences from the control values are ma-

rked ; $*(\mathrm{p}<0.05)$.

果7を裏付けるものと思われる.

各種エステラーゼの阻害剂を用い, 血漿, 肝お よび小腸ミクロソームでの SV 加水分解反応に 及ぼす影響について検討した。血漿では，有機り ン剂である DFP により加水分解反応は完全に 阻害され，カルボキシルェステラーゼの阻害剤で ある BNPP では用量依存的に阻害された。 ア セチルコリンエステラーゼおよびュリンエステ ラーゼの阻害剤である Phys は高濃度でのみ加 水分解を阻害した. 各種エステラーゼの基質を用 いて加水分解反応に及ぼす影響を調べた結果, カ ルボキシルェステラーゼの基質である $\alpha-\mathrm{NA} て ゙$ 用量依存的に阻害されたが，アセチルコリンェス テラーゼおよびュリンェステラーゼの基質である $\mathrm{ACh}$ 扎よび BzCh によっては, 何ら影響を受 けなかった。 また， $\delta$-GL 扣よび MVL はとも に生体内に存在するラクトン環を持つ化合物であ り，これらはそれぞれסーグルコノラクトンハイド
ロラーゼ12) 拈よびメバロノラクトンハイドロ ラーゼ13）の特異的基質である，そこでこれら二 種の基質による影響を調べたが，SV のラクトン 環の加水分解反応には何の影響もみられなかった。 また，金属キレート剤である EDTA の添加に よっても加水分解反応は何の影響も受けなかった. 有機リン剂である DFP および BNPP は, 活 性中心にセリン残基を持つカルボキシルェステ ラーゼに強く結合し，リン酸化によってその酵素 活性を阻害することが知られている14,15). また， Phys はアセチルコリンエステラーゼおよびュリ ンエステラーゼの阻害剤であるが, ともに活性中 心にセリン残基を持つコリンェステラーゼに結合 し, カルバモイル化によってその酵素活性を阻害 することが知られている10). これらの結果から, 血漿中の SV 加水分解酵素は, 活性中心にセリ ン残基を持ったある種のカルボキシルエステラー ゼである可能性が強く示唆された. 肝ミクロソー 
ムでは, DFP および BNPP により加水分解反 応は用量依存的に阻害されたが, Phys では阻害 されなかった，各酵素の特異的基質を用いてその 影響を調べたところ， $\alpha-\mathrm{NA}$ は SV 加水分解反 応を用量依存的に阻害したが， ACh， BzCh， $\delta^{-}$ GL および MVL は全く阻害しなかった。 また, EDTA は，加水分解反応を用量依存的に阻害し た. 肝ミクロソーム中加水分解酵素も, 血漿と同 様にある種のカルボキシルエステラーゼである可 能性が考古られるが, 阻害パターンの違いから, 血漿中加水分解酵素とは性質の異なる酵素である ことが示唆された，一方，小腸ミクロソームでは， DFP， BNPP および Phys のいずれによって も SV の加水分解反応は阻害されなかった。一 般に, カルボキシルエステラーゼやュリンエステ ラーゼは，DFP により酵素活性を著しく阻害さ れるが, アリルェステラーゼの活性は DFP で は阻害されないことが知られている14). そこで, アリルェステラーゼの基質である $\mathrm{PhA}$ を用い て, 酵素活性に及ぼす影響を検討したが，SVの 加水分解は阻害されなかった. 同様に $\delta$-GL や MVL などの基質による影響も調べたが，いず れによっても加水分解反応は阻害されなかった。

また，EDTA による金属イオンの影響を調べた が，父の阻害作用は弱いが加水分解反応を用量依 存的に阻害した。 これらの結果は SV の小腸で の加水分解が，カルボキシルェステラーゼあるい はラクトンハイドロラーゼとは別の酵素によって 起こっている可能性が考兄られる。なお，肝およ び小腸ミクロソームでみられた EDTA による 阻害効果は加水分解酵素に金属イオンが存在する のか，あるいは co-factor として必要であるの かは現在不明である.

本研究の結果より, SV は主として血漿中カル ボキシルェステラーゼによって加水分解され，ま た，各組織中のエステラーゼはおの打の性質が異 なっており，特に小腸の加水分解酵素は，血漿お よび肝蔵中の酵素とは全く性質の異なる酵素であ る可能性が示唆された. 現在, この特異的な小腸 エステラーゼの精製について検討を進めている.

\section{要 約}

雄性 Sprague-Dawly 系ラットの血漿, 肝臓
および小腸ミクロソームを用いて, simvastatin (SV) からそのオープンアシッド体（SVA）へ の加水分解酵素の性質について比較した.

1. $\mathrm{SV}$ は $\mathrm{pH} 3 \sim 6$ の範囲では, $37^{\circ} \mathrm{C}, 30$ 分間のインキュベーションによっても非酵素的加 水分解をほとんど受けなかったが，pH４以上で は速やかに加水分解された。

2. 血漿, 肝および小腸ミクロソームの加水分 解酵素活性に及ぼす $\mathrm{pH}$ の影響を調べた結果, 血漿，肝抢よび小腸ミクロソームでの至適 $\mathrm{pH}$ は $7 \sim 8$ 付近であった。

3. 各組織での $\mathrm{pH} 7.2$ におけるVmax值は, 血漿で $0.33 \mathrm{nmol} / \mathrm{min} / \mathrm{mg}$ protein であり, 肝蔵 および小腸ではそれぞれ0.97および $0.24 \mathrm{nmol} /$ min/mg protein であった. $\mathrm{Km}$ 值は, 血漿, 肝臓および小腸でそれぞれ21.9，203.3 おおよ゙゙ $567.6 \mu \mathrm{M}$ であった. $\mathrm{V} \max / \mathrm{Km}$ 值を各組織間で 比較すると血漿が最高值を示し，肝の3.2 倍，小 腸の38倍であった.

4. 各種のエステラーゼ阻害剤を用いて，SV から SVA への加水分解反応に及ぼす影響を調 ベた。血漿では, diisopropyl fluorophosphate (DFP) の添加によりその加水分解反応はほぼ完 全に阻害され, bis ( $\mathrm{p}$-nitrophenyl) phosphate （BNPP）では用量依存的に阻害された。をた， physostigmine (Phys) では, 高濃度の添加に よってのみ阻害された。肝臓では, DFP および BNPPにより用量依存的に阻害されたが，Phys では何ら影響を受けなかった、一方，小腸では， DFP，BNPP および Phys のいずれによって も加水分解反応は阻害されなかった。 また, EDTA の添加により, 肝臓および小腸での加水 分解反応は用量依存的に阻害されたが，血漿では 何ら影響を受けなかった．血漿中の SV 加水分 解酵素は，その活性中心にセりン残基をもつある 種のカルボキシルエステラーゼの可能性が示唆さ れた、肝ミクロソームでの SV の加水分解反応 にもカルボキシルェステラーゼの関与が示唆され たが，血漿中酵素とは性質が異なると思われた。 一方, 小腸ミクロソームでの加水分解反応は, 血 漿および肝ミクロソームとはまったく性質の異な る加水分解酵素の関与が示唆された. 


\section{文献}

1) Hoffman, W.F., Alberts, A.W., Anderson, P.S., Chen, J.S., Smith, R. L. and Willard, A.K. : 3-Hydroxy-3-methylglutaryl-coenzyme A reductase inhibitors. 4. side chain ester derivatives of mevinolin. J. Med. Chem., $29: 849-852$ (1986).

2) Alberts, A.W., Chen, J., Huff, J., Hunt, V. and Kuron, G. : Comparative studies on the hydroxymethylglutaryl coenzyme A reductase inhibitors mevinolin, MK-733, and CS-514. Proceedings of the X th Intl. Symp. Drugs Affect Lipid Metab. (Florence), : 8 (1986).

3) Ishida, F., Sato, A., Iizuka, Y., Sawasaki, Y., Aizawa, A. and Kamei, T. : Effects of MK-733, an inhibitor of 3-hydroxy-3-methylglutary-coenzyme A reductase, on absorption and excretion of $\left[{ }^{3} \mathrm{H}\right]$ cholesterol in rabbits. Biochem. Biophys. Acta., 963 : 35-41 (1988).

4) Kobayashi, M., Ishida, F., Takahashi, T., Taguchi, K., Watanabe, K., Ohmura, I. and Kamei, T. : Preventive effect of MK-733 (simvastatin), an inhibitor of $\mathrm{HMG}^{-} \mathrm{CoA}$ reductase, on hypercholesterolemia and atherosclerosis induced by cholesterol feeding in rabbits. Japan J. Pharmacol., 49 : 125-133 (1989).

5）中谷矩章, 五島雄一郎：抗高脂血症剂 MK-7330第 I 相臨床試験 (第 1 報) 健常人 における単回投与および連続投与試験成績. 臨床医薬，5：1097-1121 (1989).

6) Vickers, S., Duncan, C. A., Chen, I. -WU, Rosegay, A. and Duggan, D.E. : Metabolic disposition studies on simvastatin, a cholesterol-lowering prodrug. Drug Metab. Dispos., 18 : 138-145 (1990).

7）内山尚孝，斉藤由子，加々見弥生，原 健一，斉藤 郁，沢崎芳男，大多和昌克：高 脂血症治療薬 Simvastatin の体内動態（第 1 報）：ラットにおける単回投与後の吸 収・分布・代謝・排泄. 薬物動態, 5: 133-149（1990）.

8) Lowry, O.H., Rosebrough, N.J., Farr, A.L. and Randall, R.J. : Protein measurement with the folin phenol reagent. J. Biol. Chem., $193: 265-275$ (1951).

9）中村隆雄 : 酵素一反応速度論と機構, 学会出版センター：92-95 (1986).

10) Williams, F.M., Mutch, E. and Blain, P.G. : Esterase activity in rat hepatocytes. Biochem. Pharmacol., 41(4): 527-531 (1991).

11) Ohta, N., Kurono Y. and Ikeda, K. : Esterase-like activity of human serum albumin II : reaction with $\mathrm{N}$-trans-cinnamoylimidazoles. J. Pharmac. Sci., $72:$ 385-388 (1983).

12) Kawada, M., Kagawa, Y., Takiguchi, H. and Shimazono, N. : Purification of 6-phosphogluconolactonase from rat liver and yeast; its separation from gluconolactonase. Biochim. Biophys. Acta., 57 : 404-407 (1962).

13) Wiley, M.H., Huling, S. and Siperstein, M.D. : Conversion of mevalonolactone to its open-chain salt by a serum enzyme. Biochem. Biophys. Res. Commun., 88 : 605-612 (1979).

14) Brandt, E., Heymann, E. and Mentlein, R. : Selective inhibition of rat liver carboxylesterases by various organophosphorus diesters in vivo and in vitro. Biochem. Pharmacol., 29 : 1927-1931 (1980).

15) Mackness, M.I. : Commentary, 'A'-esterases-Enzymes looking for a role. Biochem. Pharmacol., 38(3) : 385-390 (1989). 